\title{
Resistance to Septoria lycopersici in Solanum (section Lycopersicon) species and in progenies of S. lycopersicum $\times$ S. peruvianum
}

\author{
Jaqueson Ferreira Satelis; Leonardo Silva Boiteux; Ailton Reis* \\ Embrapa Hortaliças, C.P. 0218 - $70359-970$ - Brasília, DF - Brasil. \\ *Corresponding author < ailton@cnph.embrapa.br>
}

\begin{abstract}
Septoria leaf spot (Septoria lycopersici) is one of the major fungal diseases of tomatoes (Solanum lycopersicum) in tropical and subtropical regions with humid climates and/or in areas cultivated under sprinkler irrigation systems. Sources of resistance have been found in accessions of Solanum (section Lycopersicon) species. However, many of the described sources are not effective under Brazilian conditions. The objective of this work was to evaluate wild and cultivated Solanum (section Lycopersicon) germplasm to S. lycopersici isolates. A collection of 124 accessions was initially evaluated under greenhouse conditions. Ten accessions were highly resistance (HR), whereas 33 were classified as having a resistant $(\mathrm{R})$ response to S. lycopersici isolates. Field evaluation was also conducted with a sub-set of accessions identified as either HR or R in the greenhouse experiment. This field evaluation confirmed greenhouse tests and indicated the presence of some potential sources of rate-reducing resistance. One highly resistant and eight resistant $S$. habrochaites accessions were identified as being resistant under both conditions, confirming that this wild species is one of the most promising sources of resistance to $S$. lycopersici. Five new sources with high levels of resistance were found in S. peruvianum accessions (PI-306811, CNPH-1036, LA-1910, LA-1984 and LA-2744). One accession derived from an interspecific cross between S. lycopersicum and S. peruvianum was also found to be highly resistant and might be useful to introgress resistance factors from this wild species into cultivated tomato germplasm. However, additional breeding efforts will be necessary to introgress into the cultivated tomato the resistance factors identified in other S. peruvianum accessions due to the presence of natural crossing barriers between the two species.
\end{abstract}

Key words: breeding, disease control, septoria leaf spot

\section{Resistência a Septoria lycopersici em espécies de Solanum (Seç̧ão Lycopersicon) e em progênies de $S$. lycopersicum $\times S$. peruvianum}

\begin{abstract}
RESUMO: A mancha-de-septória (Septoria lycopersici) é importante doença fúngica do tomateiro (Solanum lycopersicum) em áreas tropicais e subtropicais com alta umidade ou quando esta hortaliça é cultivada sob irrigação por aspersão. Fontes de resistência têm sido encontradas em germoplasma de Solanum (secção Lycopersicon). No entanto, muitas das fontes descritas não funcionam nas condições brasileiras. Avaliou-se uma coleção de germoplasma de tomate cultivado e selvagem (Solanum secção Lycopersicon) visando identificar novas fontes de elevada resistência. Uma coleção de 124 acessos foi inicialmente avaliada sob condições de casa de vegetação. Somente dez acessos foram classificados como altamente resistentes e 33 foram classificados como resistentes. Um ensaio de campo foi também conduzido com um subconjunto de acessos promissores identificados no primeiro experimento. Foi confirmada a resposta da maioria dos acessos avaliados em casa de vegetação e indicou a presença de fontes de resistência capazes de reduzir a taxa de progresso da doença. Um acesso de $S$. habrochaites com elevada resistência e oito acessos resistentes foram identificados, confirmando que esta espécie representa uma das mais promissoras fontes de genes de resistência a $S$. lycopersici. Cinco novas fontes com elevados níveis de resistência foram identificadas em acessos da espécie S. peruvianum (PI-306811, CNPH1036, LA-1910, LA-1984 e LA-2744). Um acesso, derivado de cruzamento interespecífico entre S. lycopersicum e S. peruvianum também mostrou-se altamente resistente e poderá ser útil na introgressão deste(s) gene(s) em germoplasma de tomateiro cultivado. No entanto, esforços adicionais de melhoramento serão necessários para transferir para o tomateiro cultivado os fatores de resistência identificados em outros acessos de S. peruvianum, uma vez que existem barreiras naturais de cruzamentos entre estas duas espécies.

Palavras-chave: controle de doença, melhoramento genético, mancha-foliar-de-septoria
\end{abstract}

\section{Introduction}

Septoria leaf spot, caused by the fungus Septoria lycopersici Speg., is one of the major fungal diseases of the cultivated tomato (Solanum lycopersicum L. section Lycopersicon [Mill.] Wettst. subsection Lycopersicon) in 
tropical and subtropical areas with high humidity and/ or cultivated under sprinkler irrigation systems where severe fruit yield and quality losses might occur (Jones et al., 1991).

Sources of resistance to $S$. lycopersici have been found in germplasm of wild tomatoes [Solanum L. subsection Lycopersicon, an autonym of Solanum section Lycopersicon (Mill.) Wettst.) (Peralta et al., 2005)] evaluated under either field conditions with natural inoculum (Barksdale, 1982; Maluf et al., 1985; Poysa \& Tu, 1993) or under controlled greenhouse conditions using spore suspensions (Locke, 1949; Kurozawa \& Balmer, 1977; Barksdale \& Stoner, 1978; Sotirova \& Rodeva, 1990; Moretto \& Barreto, 1993). Sources of resistance due to the presence of putative single dominant genes have been identified in accessions of S. lycopersicum 'Targinnie Red' (= LA-1800) (Andrus \& Reynard, 1945) and S. pimpinellifolium PI422397 (Barksdale \& Stoner, 1978). However, this resistance appears to be unstable (Andrus \& Reynard, 1945). Accessions derived from these two sources were shown to have intermediate to susceptible responses to $S$. lycopersici isolates in Brazil (Maluf et al., 1985).

Chemical control with fungicides is currently the method recommended for Septoria leaf spot control (Tu and Poysa, 1990). However, this strategy might be ineffective when the disease reaches certain severity levels, especially in highly susceptible cultivars (Jones et al., 1991). In this scenario, the identification of resistant sources with stable phenotypic response in different environments and effective against distinct $S$. lycopersici isolates would be an important contribution for tomato breeding programs and would help minimize the need of fungicides in the management of the tomato crop. The main objective of this study was to evaluate a diverse germplasm collection of Solanum (section Lycopersicon) for resistance to $S$. lycopersici under both greenhouse and field conditions.

\section{Material and Methods}

\section{Plant material}

Two experiments were conducted: one under greenhouse condition and one under field conditions, aiming to confirm the greenhouse results. One hundred-twentyfour accessions of cultivated and wild Solanum (section Lycopersicon) species were initially evaluated for resistance to $S$. lycopersici under greenhouse conditions in Brasília-DF, Brazil (latitude $15^{\circ} 46^{\prime} 47^{\prime \prime}$ and longitude $\left.47^{\circ} 55^{\prime} 47^{\prime \prime}\right)$. The germplasm collection under evaluation (Table 1) comprised the following accessions: 42 S. lycopersicum L. (= Lycopersicon esculentum); $07 \mathrm{~S}$. lycopersicum var. cerasiforme; $13 \mathrm{~S}$. pimpinellifolium L. (= L. pimpinellifolium); one S. chilense (Dunal) Reiche (= L. chilense); one S. pennellii (Corr.) D'Arcy (= L. pennellii); 12 S. habrochaites Knapp \& Spooner (= L. birsutum) and 42 accessions belonging to $S$. peruvianum L. (Peralta et al., 2005; Spooner et al., 2005). Six inbred lines derived from interspecific crosses between $S$. lycopersicum $\times S$. peruvianum accessions obtained by the
Brazilian tomato breeding program were also included in this evaluation. A sub-group of 17 accessions classified as either resistant or highly resistant based on the greenhouse test were also evaluated for S. lycopersici resistance under field conditions. Three S. lycopersicum accessions (classified as highly susceptible in the greenhouse test) were included as controls. Some accessions that displayed high levels of resistance in the greenhouse experiment were not included in the field experiment due to seed germination problems (e.g. LA-1270, CNPH1112 and CNPH-0633).

Septoria lycopersici isolates, inoculum production, and conidial concentration for the greenhouse and for the field experiments

The S. lycopersici isolate used in the greenhouse experiment was obtained from an infected tomato plant in the Brasília-Federal District. The spore suspension for the field experiment was a mixture of two isolates of $S$. lycopersici from tomatoes obtained from distinct geographical origins (one collected in Brasília-Federal District and the other in Morrinhos, state of Goiás, Brazil). This mixture of isolates was used aiming to challenge the germplasm collection with a more diversified pool of pathogen isolates. However, no information was available about differences in virulence and aggressiveness of these isolates. All isolates were cultivated on Potato Dextrose Agar medium for 15 days in a BOD incubator (12 $\mathrm{h}$ in the dark and $12 \mathrm{~h}$ with black light). For the greenhouse experiment, the entire plants were spray-inoculated until run-off ( $15 \mathrm{~d}$ after transplant) with a suspension adjusted to $10^{5}$ conidia per $\mathrm{mL}$. For the field experiment, plants were sprayed at $21 \mathrm{~d}$ after transplanting with a spore suspension adjusted to $10^{4}$ conidia per $\mathrm{mL}$. Conidial concentration of the field experiment was lower than that of the greenhouse experiment aiming to emulate inoculum pressure under field (natural) conditions, which is usually not so high.

\section{Greenhouse evaluation}

Seeds were sown in Styrofoam trays with 128 cells filled with sterile Plantmax ${ }^{\circledR}$ substrate. Twenty days after sowing the seedlings were transplanted to $2 \mathrm{~L}$ plastic pots filled with a sterilized mixture of an Oxisol (150 $\mathrm{L})$, sand (50 L) and organic matter (50 L of cow manure) plus $300 \mathrm{~g}$ of N-P-K (formulation 4-14-8) and $350 \mathrm{~g} \mathrm{CaO}$. The experiment set-up was a complete randomized block design with four replications (pots with three plants each) per accession. Plants of the accessions under evaluation and controls were kept in a damp chamber for $36 \mathrm{~h}$ after inoculation. Plants were cultivated under greenhouse conditions (air temperature varying from $24^{\circ} \mathrm{C}$ to $35^{\circ} \mathrm{C}$ ).

Disease severity was assessed $15 \mathrm{~d}$ after inoculation using an ordinal leaf damage scale adapted from Maluf et al. (1985): (0 to 5) where: 0 = plant free of symptoms; $1=$ foliar lesions limited to the third basal part of the plants, several lesions on bottom leaves but without coalescence of lesions; 2 = top section of the plants free of 
Table 1 - Reaction of 124 wild, cultivated and inbred lines of Solanum (section Lycopersicon) accessions to Septoria leaf spot (Septoria lycopersici) under greenhouse conditions in Brasília-DF.

\begin{tabular}{|c|c|c|c|}
\hline Accession code & Solanum (Section Lycopersicon) species & DSI* & Group of Reaction** \\
\hline LA-1910 & S. peruvianum & $6.50 \mathrm{~A}$ & HR \\
\hline CNPH-1036 & S. peruvianum & $8.50 \mathrm{~A}$ & HR \\
\hline LA-1984 & S. peruvianum & $10.00 \mathrm{~A}$ & HR \\
\hline PI-306811 & S. peruvianum & $11.50 \mathrm{~A}$ & HR \\
\hline CNPH-0979 & lyc $x$ per**** & $14.50 \mathrm{~A}$ & HR \\
\hline LA1677 & S. peruvianum & $17.00 \mathrm{~A}$ & HR \\
\hline LA-2744 & S. peruvianum & $17.50 \mathrm{~A}$ & HR \\
\hline LA-1113-1 & S. peruvianum & $21.50 \mathrm{~A}$ & HR \\
\hline CNPH-1112 & S. habrochaites & $23.50 \mathrm{~A}$ & HR \\
\hline TX-407 & lyc $x$ per $* * *$ & $25.00 \mathrm{~A}$ & HR \\
\hline WIR-3611 & S. habrochaites & $26.00 \mathrm{~B}$ & $\mathrm{R}$ \\
\hline LA-0107 & S. peruvianum & $26.50 \mathrm{~B}$ & $\mathrm{R}$ \\
\hline LA-1113-2 & S. peruvianum & $28.50 \mathrm{~B}$ & $\mathrm{R}$ \\
\hline PI-126445 & S. habrochaites & $30.00 \mathrm{~B}$ & $\mathrm{R}$ \\
\hline PI-134417 & S. babrochaites & $30.00 \mathrm{~B}$ & $\mathrm{R}$ \\
\hline LA-1270 & S. peruvianum & $30.00 \mathrm{~B}$ & $\mathrm{R}$ \\
\hline TX-410 & lyc $x$ per*** & $30.00 \mathrm{~B}$ & $\mathrm{R}$ \\
\hline CGO-6711 & S. peruvianum & $31.50 \mathrm{~B}$ & $\mathrm{R}$ \\
\hline LS-121 & S. peruvianum & $31.50 \mathrm{~B}$ & $\mathrm{R}$ \\
\hline LA-1967 & S. chilense & $32.50 \mathrm{~B}$ & $\mathrm{R}$ \\
\hline PI-127826 & S. habrocbaites & $33.00 \mathrm{~B}$ & $\mathrm{R}$ \\
\hline PI-134418 & S. babrochaites & $33.00 \mathrm{~B}$ & $\mathrm{R}$ \\
\hline CGO-6708 & S. peruvianum & $33.00 \mathrm{~B}$ & $\mathrm{R}$ \\
\hline TX-412 & lyc $x$ per**** & $33.50 \mathrm{~B}$ & $\mathrm{R}$ \\
\hline CGO-6716 & S. peruvianum & $34.50 \mathrm{~B}$ & $\mathrm{R}$ \\
\hline LA-2067 & S. peruvianum & $34.50 \mathrm{~B}$ & $\mathrm{R}$ \\
\hline PI-127827 & S. habrochaites & $34.50 \mathrm{~B}$ & $\mathrm{R}$ \\
\hline WYR-7924 & S. habrochaites & $35.00 \mathrm{~B}$ & $\mathrm{R}$ \\
\hline CNPH-0633 & S. cerasiforme & $36.50 \mathrm{~B}$ & $\mathrm{R}$ \\
\hline Hawaii-7996 & S. lycopersicum & $36.50 \mathrm{~B}$ & $\mathrm{R}$ \\
\hline Santa Cruz & S. lycopersicum & $38.00 \mathrm{~B}$ & $\mathrm{R}$ \\
\hline CGO-6709 & S. peruvianum & $38.00 \mathrm{~B}$ & $\mathrm{R}$ \\
\hline L-03683 & S. habrocbaites & $38.00 \mathrm{~B}$ & $\mathrm{R}$ \\
\hline CNPH-0769 & S. pimpinellifolium & $38.50 \mathrm{~B}$ & $\mathrm{R}$ \\
\hline CNPH-1033 & S. peruvianum & $38.50 \mathrm{~B}$ & $\mathrm{R}$ \\
\hline ID-8624 & S. peruvianum & $40.00 \mathrm{~B}$ & $\mathrm{R}$ \\
\hline CGO-8200 & S. peruvianum & $41.50 \mathrm{~B}$ & $\mathrm{R}$ \\
\hline PI-126925 & S. pimpinellifolium & $42.00 \mathrm{~B}$ & $\mathrm{R}$ \\
\hline LA-1342 & S. pimpinellifolium & $42.00 \mathrm{~B}$ & $\mathrm{R}$ \\
\hline PI-128660 & S. peruvianum & $42.00 \mathrm{~B}$ & $\mathrm{R}$ \\
\hline PI-365951 & S. peruvianum & $42.50 \mathrm{~B}$ & $\mathrm{R}$ \\
\hline LA-1626 & S. peruvianum & $42.50 \mathrm{~B}$ & $\mathrm{R}$ \\
\hline CNPH-0980 & lyc $x$ per**** & $43.00 \mathrm{~B}$ & $\mathrm{R}$ \\
\hline
\end{tabular}


Table 1 - Continuation.

\begin{tabular}{|c|c|c|c|}
\hline CNPH-1592 & S. lycopersicum & $44.00 \mathrm{C}$ & $S$ \\
\hline LA-111 & S. peruvianum & $44.50 \mathrm{C}$ & S \\
\hline CGO 6712 & S. peruvianum & $45.00 \mathrm{C}$ & S \\
\hline CNPH-0841 & S. cerasiforme & $45.00 \mathrm{C}$ & S \\
\hline LA-1113-3 & S. peruvianum & $45.00 \mathrm{C}$ & S \\
\hline PI-126449 & S. habrochaites & $46.50 \mathrm{C}$ & S \\
\hline CNPH-0483 & S. lycopersicum & $46.50 \mathrm{C}$ & S \\
\hline CNPH-0610 & S. peruvianum & $46.50 \mathrm{C}$ & S \\
\hline CNPH-1097 & S. cerasiforme & $46.50 \mathrm{C}$ & S \\
\hline CGO-7650 & S. pimpinellifolium & $46.50 \mathrm{C}$ & S \\
\hline CNPH-1035 & S. peruvianum & $48.00 \mathrm{C}$ & S \\
\hline XP-674 & S. lycopersicum & $48.50 \mathrm{C}$ & S \\
\hline LA-1584 & S. pimpinellifolium & $48.50 \mathrm{C}$ & S \\
\hline C-28 & S. lycopersicum & $48.50 \mathrm{C}$ & S \\
\hline LA-441 & S. peruvianum & $50.00 \mathrm{C}$ & S \\
\hline CNPH-0641 & S. lycopersicum & $50.00 \mathrm{C}$ & S \\
\hline BHRS-1,2,3 & S. lycopersicum & $50.00 \mathrm{C}$ & S \\
\hline LA-1614 & S. pimpinellifolium & $50.00 \mathrm{C}$ & S \\
\hline Rauti & S. lycopersicum & $50.00 \mathrm{C}$ & S \\
\hline L-03708 & S. pimpinellifolium & $50.00 \mathrm{C}$ & S \\
\hline Yoshimatsu & S. lycopersicum & $50.00 \mathrm{C}$ & S \\
\hline Saladette & S. lycopersicum & $51.50 \mathrm{C}$ & S \\
\hline IVT-4 & lyc $x$ per**** & $51.50 \mathrm{C}$ & S \\
\hline WYR-2020 & S. peruvianum & $51.50 \mathrm{C}$ & S \\
\hline Duradoro & S. lycopersicum & $51.50 \mathrm{C}$ & S \\
\hline Kada & S. lycopersicum & $51.50 \mathrm{C}$ & S \\
\hline LA-1333 & S. peruvianum & $52.00 \mathrm{C}$ & S \\
\hline LA-462 & S. peruvianum & $52.00 \mathrm{C}$ & S \\
\hline VFN-8 & S. lycopersicum & $53.00 \mathrm{C}$ & S \\
\hline Heinz 439 & S. lycopersicum & $53.50 \mathrm{C}$ & S \\
\hline CGO 6707 & S. peruvianum & $53.50 \mathrm{C}$ & S \\
\hline LA-1609 & S. peruvianum & $53.50 \mathrm{C}$ & S \\
\hline LA-2553 & S. peruvianum & $53.50 \mathrm{C}$ & S \\
\hline LA-385 & S. peruvianum & $54.50 \mathrm{C}$ & S \\
\hline WYR-3951 & S. habrochaites & $54.67 \mathrm{C}$ & S \\
\hline AG-551 & S. cerasiforme & $55.00 \mathrm{C}$ & S \\
\hline CNPH-1034 & S. habrochaites & $55.00 \mathrm{C}$ & S \\
\hline Rutgers & S. lycopersicum & $55.00 \mathrm{C}$ & S \\
\hline TSW-10 & S. lycopersicum & $55.00 \mathrm{C}$ & S \\
\hline LA-1425 & S. cerasiforme & $56.00 \mathrm{C}$ & S \\
\hline CGO-6714 & S. peruvianum & $56.50 \mathrm{C}$ & S \\
\hline LA-1616 & S. peruvianum & $56.50 \mathrm{C}$ & S \\
\hline Overpack & S. lycopersicum & $56.50 \mathrm{C}$ & S \\
\hline CNPH-0889 & S. lycopersicum & $56.50 \mathrm{C}$ & $\mathrm{S}$ \\
\hline CNPH-199 & S. lycopersicum & $58.00 \mathrm{D}$ & HS \\
\hline
\end{tabular}


Table 1 - Continuation.

\begin{tabular}{|c|c|c|c|}
\hline CNPH-1412 & S. cerasiforme & $58.00 \mathrm{D}$ & HS \\
\hline LA-716 & S. pennellii & $58.50 \mathrm{D}$ & HS \\
\hline WYR-3957 & S. peruvianum & $58.50 \mathrm{D}$ & HS \\
\hline Hawaii-7998 & S. lycopersicum & $58.50 \mathrm{D}$ & HS \\
\hline Viradoro & S. lycopersicum & $60.00 \mathrm{D}$ & HS \\
\hline $732293-2 v$ & S. pimpinellifolium & $60.00 \mathrm{D}$ & HS \\
\hline Ãngela Gigante & S. lycopersicum & $60.00 \mathrm{D}$ & HS \\
\hline PI-128659 & S. peruvianum & $60.00 \mathrm{D}$ & HS \\
\hline Florida Petit & S. lycopersicum & $60.00 \mathrm{D}$ & HS \\
\hline CNPH-1358 & S. lycopersicum & $60.00 \mathrm{D}$ & HS \\
\hline Floradade & S. lycopersicum & $60.50 \mathrm{D}$ & HS \\
\hline IPA-5 & S. lycopersicum & $61.50 \mathrm{D}$ & HS \\
\hline WC-134 & S. lycopersicum & $61.50 \mathrm{D}$ & HS \\
\hline IVT-3 & S. lycopersicum & $61.50 \mathrm{D}$ & HS \\
\hline CGO-6713 & S. peruvianum & $61.50 \mathrm{D}$ & HS \\
\hline CNPH-1039 & S. pimpinellifolium & $62.00 \mathrm{D}$ & HS \\
\hline PI-732293 & S. pimpinellifolium & $62.00 \mathrm{D}$ & HS \\
\hline L-03707 & S. pimpinellifolium & $62.00 \mathrm{D}$ & HS \\
\hline Ohio-8245 & S. lycopersicum & $62.00 \mathrm{D}$ & HS \\
\hline Alambra & S. lycopersicum & $62.00 \mathrm{D}$ & HS \\
\hline BRA-013307 & S. lycopersicum & $63.50 \mathrm{D}$ & HS \\
\hline CNPH-0374 & S. peruvianum & $63.50 \mathrm{D}$ & HS \\
\hline CNPH-0956 & S. lycopersicum & $63.50 \mathrm{D}$ & HS \\
\hline Ponderosa & S. lycopersicum & $63.50 \mathrm{D}$ & HS \\
\hline CNPH-0239 & S. lycopersicum & $65.00 \mathrm{D}$ & HS \\
\hline Santa Clara & S. lycopersicum & $65.00 \mathrm{D}$ & HS \\
\hline LA-2172 & S. peruvianum & $65.00 \mathrm{D}$ & HS \\
\hline PI-126445 & S. pimpinellifolium & $65.00 \mathrm{D}$ & HS \\
\hline BHRS-2.3 & S. lycopersicum & $67.00 \mathrm{D}$ & HS \\
\hline Glamour & S. lycopersicum & $67.00 \mathrm{D}$ & HS \\
\hline San Vito & S. lycopersicum & $67.00 \mathrm{D}$ & HS \\
\hline WYR-2920 & S. pimpinellifolium & $70.00 \mathrm{D}$ & HS \\
\hline New Yorker & S. lycopersicum & $70.00 \mathrm{D}$ & HS \\
\hline Yuba & S. lycopersicum & $70.00 \mathrm{D}$ & HS \\
\hline CNPH-0390 & S. cerasiforme & $70.00 \mathrm{D}$ & HS \\
\hline MoneyMaker & S. lycopersicum & $70.00 \mathrm{D}$ & HS \\
\hline CV (\%) & & $11.20 \%$ & \\
\hline
\end{tabular}

"DSI (Disease Severity Index) $=[\mathrm{S}$ (disease rate $\times$ number of plants in each disease rate $) /($ total number of evaluated plants $\times$ maximum disease rate) $] \times 100$. Disease ratings ranged from 0 to 5 where: $0=$ no symptoms and $5=$ plant displaying several foliar lesions. DSI values followed by the same letter in the column belong to the same cluster according to the Scott-Knott cluster analysis method $(p=0.05)$; **The four reaction groups were assigned as follow: $\mathrm{HR}=$ highly resistant; $\mathrm{R}=$ resistant; $\mathrm{S}=$ susceptible and HS $=$ highly susceptible; $* * *$ Lines derived from interspecific crosses between S. lycopersicum and S. peruvianum.

foliar lesions, many lesions present on the basal leaves, but with rare coalescence; $3=$ top section of the plants free of foliar lesions, many lesions on the basal leaves of the plants, frequently coalescent; $4=$ top section of the plants free of foliar lesions, many lesions on leaves located in medium portion of the plants with coales- cence, but rarely getting $50 \%$ of foliar area; $5=$ top of the plant displaying several foliar lesions, many lesions on the intermediary and basal leaves with coalescence, lesions covering more than $50 \%$ of the foliar area, presence of premature leaf drop. With the obtained data a disease severity index (DSI) was calculated for each ac- 
cession on each replicate (McKinney, 1923), using the following expression: DSI $=[\Sigma($ disease rate $\times$ number of plants in each rate)/(total number of evaluated plants $\times$ maximum disease rate) $] \times 100$. The DSI data were transformed into $\sqrt{x+0.5}$. The Scott-Knott $(p=0.05)$ cluster analysis method for grouping means in the analysis of variance was employed with the numerical data (Scott and Knott, 1974).

\section{Field evaluation}

The field experiment was conducted in Brasília-DF using a randomized complete block design with four replications (24 plants each). The soil type was a clayey dystrophic Oxisol. The experimental plots were sprayed at a weekly basis with insecticides for the control of whiteflies (Bemisia tabaci) and South America moth (Tuta absoluta). Plots were sprinkler irrigated in order to keep the soil close to water saturation and provide the foliage with free water aiming to favor S. lycopersici epidemics. The irrigation regime was determined by monitoring water potential levels with a soil moisture tensiometer. The average air temperature during the field experiment was $23^{\circ} \mathrm{C}$ with a range of $17^{\circ} \mathrm{C}$ (night temperature) to $28^{\circ} \mathrm{C}$ (day temperature). Field plots were overhead irrigated two hours before inoculation to increase the wetness and soil moisture. Inoculation was performed just before sunset, spraying the spore suspension on the entire plants until run-off. The assessments of the disease severity were made on the four center plants in each plot, starting 15 days after inoculation. Disease assessments were performed every seven days for five weeks. A disease severity index (DSI) was calculated for each plot essentially as described before for the greenhouse evaluation (McKinney, 1923). The area under disease progress curves (AUDPC) were generated using DSI values, where: AUDPC $=\left\{\Sigma\left[\left(\mathrm{y}_{\mathrm{i}}+\mathrm{y}_{\mathrm{i}+1}\right) / 2\right] \cdot\left(\mathrm{t}_{\mathrm{i}+1}-\mathrm{t}_{\mathrm{i}}\right)\right\} / \mathrm{n}$, where $y_{i}$ and $y_{i+1}$ are the values of DSI observed between two assessments, $t_{i+1}-t_{i}$ is the time interval between assessments and $\mathrm{n}=$ elapsed time between the beginning and the end of the assessment period (Fry, 1978). DSI data were also transformed using $\sqrt{x+0.5}$ for analysis of variance using the Scott-Knott cluster analysis method $(p=$ $0.05)$ for grouping means in the analysis of variance. The AUDPC data were submitted to the analysis of variance and average comparisons, but without data transformation.

\section{Results and Discussion}

DSI and reactions to Septoria leaf spot in the 124 accessions evaluated under greenhouse conditions (Table 1) indicate that according to the Scott-Knott cluster analysis it was possible to classify the Solanum (section Lycopersicon) accessions in four reaction groups: highly resistant (HR), resistant (R), susceptible (S) and highly susceptible (HS). Approximately $8 \%$ of the tested accessions were considered HR, 26.6\% were considered $\mathrm{R}$ and most $(65.3 \%)$ were either S $(35.5 \%)$ or HS $(29.8 \%)$ to the pathogen.
The majority of the accessions from S. lycopersicum and its closely related botanical variety $S$. lycopersicum var. cerasiforme reacted in the range between $\mathrm{S}$ and HS. Therefore, as expected, the number of HR and/or R accessions within the cultivated tomato gene pool was scarce. The only exception was the accession from the subspecies $S$. lycopersicum var. cerasiforme (CNPH-0633), which was classified as $\mathrm{R}$ (Table 1). This accession is valuable due to the fact that there is no crossing barrier with S. lycopersicum. However, this accession was not evaluated under field conditions due to seed germination problems. Therefore, additional tests are needed to fully demonstrate the breeding value of this accession for Septoria leaf spot resistance.

No accession with HR response was found in the wild tomato relative (S. pimpinellifolium). Many accessions from this species displayed either S $(30.8 \%)$ or HS $(46.2 \%)$ reactions to the pathogen. A total of $23.1 \%$ was classified as $\mathrm{R}$ (Table 1). These results are not in complete agreement with other studies where many $S$. pimpinellifolium accessions were classified as highly resistant (Alexander et al., 1942; Alexander, 1959; Barksdale and Stoner, 1978; Barksdale, 1982). There are a large number of $S$. pimpinellifolium accessions available in germplasm collections throughout the world, and the ones evaluated here could represent a fraction without HR accessions.

Most of the S. habrochaites accessions were classified as $R$ in the present study. In addition, one accession of this species was classified as HR, which agrees with several previous reports in the literature (Alexander et al., 1942; Alexander, 1959; Barksdale and Stoner, 1978; Barksdale, 1982; Maluf et al., 1985). Accessions of this wild species have been reported as the most promising sources of resistance to $S$. lycopersici in Solanum (section Lycopersicon) (Alexander et al., 1942; Maluf et al., 1985). From a practical breeding standpoint, the high levels of resistance to $S$. lycopersici identified in $S$. habrochaites accessions may be extremely useful since they can be promptly introgressed into the $S$. lycopersicum gene pool. This wild species has no major crossing barriers with cultivated tomatoes when serving as staminate (pollen) donor (Hogenboom, 1972). Therefore, S. lycopersici resistance in $S$. lycopersicum could be improved by using this wild species germplasm.

Resistance to $S$. lycopersici has been already identified in some S. chilense accessions (Poysa and Tu, 1993). However, to our knowledge, it is the first formal report of resistance to Septoria leaf spot in the accession $S$. chilense LA-1967. This accession is of special value for the tomato breeding programs since it displays resistance response to an array of tomato pathogens including: Fusarium oxysporum f.sp. lycopersici race 3 (Reis et al., 2004) Tomato chlorotic mottle virus (Santana et al., 2001; Giordano et al., 2005) and potyvirus. In addition, interspecific progenies between S. lycopersicum and S. chilense LA-1967 have been obtained and the resistance to $S$. lycopersici could be incorporated into elite lines using this germplasm (Santana et al., 2001). 
Accessions with resistance factors to $S$. lycopersici seem to be more common within the $S$. peruvianum when compared with other wild species of the section Lycopersicon, confirming the results of previous screening works (Alexander et al., 1942; Alexander, 1959; Kurozawa and Balmer, 1977; Sotirova and Rodeva, 1990). In the present work, seven out of the ten highly resistant accessions were S. peruvianum (Peralta et al., 2005; Sponner et al., 2005). Five $S$. peruvianum accessions (PI306811, CNPH-1036, LA-1910, LA-1984, and LA-2744) were reported for the first time as highly resistance sources against $S$. lycopersici. In addition, fertile/self-compatible inbred lines derived from the interspecific crosses between S. lycopersicum and S. peruvianum were also classified as resistant to S. lycopersici (Table 1). The availability of these fertile, interspecific inbred lines opens the possibility of further genetic studies in order to identify the genetic factors associated with S. lycopersici resistance derived from $S$. peruvianum. So far, such studies have been conducted only with $S$. pimpinellifolium and S. habrochaites accessions (Barksdale and Stoner, 1978; Barksdale 1982; Maluf et al., 1985; Sotirova and Rodeva, 1990; Tu and Poysa, 1990).

Evaluation under field conditions of accessions with promising levels of resistance to Septoria leaf spot has been recommended as a standard procedure to confirm the resistant reaction (Barksdale, 1982). For this reason, a sub-set of 17 accessions displaying either HR or R reaction under greenhouse were also evaluated under field conditions with artificial inoculation in order to assure adequate levels of inoculum pressure. Most of the accessions selected as HR or $\mathrm{R}$ in the greenhouse experiment were also resistant in the field to the mixture of two pathogen isolates employed as inoculum. The controls confirmed their high susceptibility as well as the adequate levels of inoculum pressure (Table 2).

Transferring genes from $S$. peruvianum complex to cultivated tomatoes is very difficult via conventional crossings, but some of the genetic barriers could be overcome by in vitro embryo rescue techniques (Bhatia et al., 2004), which would allow for the introgression of genetic diversity in the cultivated tomato gene pool. The effort justifying the introgression of resistance to $S$. lycopersici from this germplasm pool is due to the possibility that they might represent sources of new genes/ alelles. In addition, many of the multiple sources of resistance reported here are also carrying useful resistance alleles to other diseases. The accession S. chilense LA1967 would deserve additional efforts especially because it has also been reported as source of resistance to other economically important tomato pathogens (Santana et al., 2001; Giordano et al., 2005).

Table 2 - Field evaluation of a sub-group of Solanum (section Lycopersicon) accessions identified with differential response to Septoria leaf blight under greenhouse conditions. Evaluation criteria were the area under disease progress curve (AUDPC) and the final disease severity index (DSI).

\begin{tabular}{|c|c|c|c|c|c|}
\hline Accession code & CNPH code & Solanum (Section Lycopersicon) species & Greenhouse evaluation*** & AUDPC & DSI \\
\hline LA-1677 & CNPH-0933 & S. peruvianum & $\mathrm{HR}$ & $323.33 \mathrm{~A}$ & $16.67 \mathrm{~A}$ \\
\hline PI-306811 & CNPH-0101 & S. peruvianum & $\mathrm{HR}$ & $408.75 \mathrm{~A}$ & $17.50 \mathrm{~A}$ \\
\hline CNPH-0979 & CNPH-0979 & S. lyc $\times$ S. per:*** & HR & $598.75 \mathrm{~A}$ & $20.00 \mathrm{~A}$ \\
\hline WIR-3611 & CNPH-0605 & S. habrochaites & $\mathrm{R}$ & $892.50 \mathrm{C}$ & $22.50 \mathrm{~A}$ \\
\hline PI-134417 & CNPH-0423 & S. babrochaites & $\mathrm{R}$ & $575.00 \mathrm{~A}$ & $25.00 \mathrm{~A}$ \\
\hline PI-126445 & CNPH-0416 & S. babrochaites & $\mathrm{R}$ & $471.25 \mathrm{~A}$ & $27.50 \mathrm{~B}$ \\
\hline LA-1984 & CNPH-1462 & S. peruvianum & HR & $528.75 \mathrm{~A}$ & $27.50 \mathrm{~B}$ \\
\hline CNPH-1036 & CNPH-1036 & S. peruvianum & HR & $821.25 \mathrm{~B}$ & $27.50 \mathrm{~B}$ \\
\hline LA-1113-2 & CNPH-0939 & S. peruvianum & $\mathrm{R}$ & $1071.25 \mathrm{C}$ & $27.50 \mathrm{~B}$ \\
\hline LA-0107 & CNPH-1435 & S. peruvianum & $\mathrm{R}$ & $923.33 \mathrm{C}$ & $30.00 \mathrm{~B}$ \\
\hline PI-127827 & CNPH-0421 & S. habrocbaites & $\mathrm{R}$ & $766.25 \mathrm{~B}$ & $30.00 \mathrm{~B}$ \\
\hline TX-407 & CNPH-0946 & S. lyc $\times$ S. per & $\mathrm{HR}$ & $792.50 \mathrm{~B}$ & $32.50 \mathrm{~B}$ \\
\hline LA-2744 & CNPH-1471 & S. peruvianum & HR & $718.33 \mathrm{~B}$ & $33.33 \mathrm{~B}$ \\
\hline LA-1967 & CNPH-0410 & S. chilense & $\mathrm{R}$ & $773.75 \mathrm{~B}$ & $35.00 \mathrm{~B}$ \\
\hline LA-1113-1 & CNPH-0938 & S. peruvianum & HR & $923.75 \mathrm{C}$ & $35.00 \mathrm{~B}$ \\
\hline LA-1910 & CNPH-1454 & S. peruvianum & HR & $705.00 \mathrm{~B}$ & $36.67 \mathrm{~B}$ \\
\hline Hawaii-7998 & CNPH-0865 & S. lycopersicum & HS & $1027.50 \mathrm{C}$ & $50.00 \mathrm{C}$ \\
\hline Yuba* & CNPH-0851 & S. lycopersicum & HS & 1666.25 D & $72.50 \mathrm{D}$ \\
\hline IPA-5* & CNPH-0507 & S. lycopersicum & HS & $1595.00 \mathrm{D}$ & $77.50 \mathrm{D}$ \\
\hline CV (\%) & -- & -- & -- & $13.45 \%$ & $14.76 \%$ \\
\hline
\end{tabular}

*Susceptible controls. $* * \mathrm{HR}=$ highly resistant; $\mathrm{R}=$ resistant; $\mathrm{S}=$ susceptible, and $\mathrm{HS}=$ highly susceptible. $* * *$ Lines derived from interspecific crosses between S. lycopersicum and S. peruvianum. 
The results reported here confirm the relative low frequency of accessions with high levels of resistance to Septoria leaf spot in the Solanum (section Lycopersicum) germplasm. Ideally, more accessions must be evaluated, and the sources of resistance discovered in this study should be re-evaluated with different isolates of the pathogen in order to confirm their stability. As discussed, strategies for controlling Septoria leaf spot in tomatoes are currently based upon fungicide sprays (Jones et al., 1991; Tu and Poysa, 1990). Accessions displaying resistance to an array of $S$. lycopersici isolates under distinct environmental conditions might represent important sources of genetic variability for tomato breeding programs. The introgression of these genetic factors in commercial tomato cultivars/inbred lines would offer effective strategies for the incorporation of stable and durable resistance to this important disease.

\section{Acknowledgements}

This work was supported by project grants of EMBRAPA; the second and third authors are recipients of a Scientific Productivity Fellowship from CNPq (MCT).

\section{References}

Alexander, S.J. 1959. Progress report of national screening of committee for disease resistance in tomato for 1954-1957. Plant Disease 43: 55-65.

Alexander, S.J.; Lincoln, R.E.; Wright, V. 1942. A survey of the genus Lycopersicon for resistance to the important tomato diseases occurring in Ohio and Indiana. Plant Disease Reporter 136: 5185 ,

Andrus, C.F.; Reynard, C.B. 1945. Resistance to Septoria leaf spot and its inheritance in tomatoes. Phytopathology 35: 16-24.

Barksdale, T.H. 1982. Control of an epidemic of Septoria leaf spot of tomato by resistance. Plant Disease 66: 239-240.

Barksdale, T.H.; Stoner, A.K. 1978. Resistance in tomato to Septoria lycopersici. Plant Disease Reporter 62: 814-817.

Bhatia, P.; Ashwath, N.; Senaratna, T.; Midmore, D. 2004. Tissue culture studies of tomato (Lycopersicon esculentum). Plant Cell, Tissue and Organ Culture 78: 1-21.

Fry, W.E. 1978. Quantification of general resistance of potato cultivars and fungicide effects for integrated control of potato late blight. Phytopathology 68: 1650-1655.

Giordano, L.B.; Silva-Lobo, V.L.; Santana, F.M.; Fonseca, M.E.N.; Boiteux, L.S. 2005. Inheritance of resistance to the bipartite Tomato chlorotic mottle begomovirus derived from Lycopersicon esculentum cv. 'Tyking'. Euphytica 143: 27-33.
Hogenboom, N.G. 1972. Breaking breeding barriers in Lycopersicon. I. The genus Lycopersicon, its breeding barriers and the importance of breaking those barriers. Euphytica 21: 221-227.

Jones, J.B; Jones, J.P.; Stall, R.E.; Zitter, T.A. 1991. Compendium of Tomato Diseases. American Phytopathological Society, St. Paul, MN, USA.

Kurozawa, C; Balmer, E. 1977. Performance of Brazilian and foreign tomato cultivars and wild species in relation to Septoria lycopersici. Summa Phytopathologica 3: 135-141 (in Portuguese, with abstract in English).

Locke, S.B. 1949. Resistance to early blight and Septoria leaf spot in the genus Lycopersicon. Phytopathology 39: 829-836.

McKinney, H.H. 1923. Influence of soil temperature and moisture on infection of wheat seedlings by Helminthosporium sativum. Journal of Agricultural Research 26: 195-218.

Maluf, W.R.; Miranda, J.E.C.; Bittencourt, C. 1985. Evaluation of Lycopersicon spp. accessions to Septoria leaf blight. Horticultura Brasileira 3: 9-11 (in Portuguese, with abstract in English).

Moretto, K.C.K.; Barreto, M. 1993. Evaluation of the reaction to Septoria lycopersici infection of seven tomato cultivars. Summa Phytopathologica 19: 18-20 (in Portuguese, with abstract in English).

Peralta, I.; Knaap, S.; Spooner, D.M. 2005. New species of wild tomatoes (Solanum section Lycopersicon: Solanaceae) from Northern Peru. Systematic Botany 30: 424-434.

Poysa, V.; Tu, J.C. 1993. Response of cultivars and breeding lines of Lycopersicon spp. to Septoria lycopersici. Canadian Plant Disease Survey 73: 9-13.

Reis, A.; Giordano, L.B.; Lopes, C.A.; Boiteux, L.S. 2004. Novel sources of multiple resistance to three races of Fusarium oxysporum f. sp. lycopersici in Lycopersicon germplasm. Crop Breeding and Applied Biotechnology 4: 495-502.

Santana, F.M.; Ribeiro, S.G.; Moita, A.W.; Moreira-Júnior, D.J.; Giordano, L.B. 2001. Sources of resistance in Lycopersicon spp. to a bipartite whitefly-transmitted geminivirus from Brazil. Euphytica 122: 45-51.

Scott, A.J.; Knott, M. 1974. A cluster analysis method for grouping means in the analysis of variance. Biometrics 30: 507-512.

Sotirova, V.; Rodeva, R. 1990. Sources of resistance in tomato to Septoria lycopersici Speg. Archiv fur Phytopathologie Pflanzenschutz 26: 469-471.

Spooner, D.M.; Peralta, I.E.; Knapp, S. 2005. Comparison of AFLPs with other markers for phylogenetic inference in wild tomatoes [Solanum L. section Lycopersicon (Mill.) Wettst.]. Taxon 54: $43-$ 61.

Tu, J.C.; Poysa, V. 1990. Method of inoculation for screening tomato seedlings for resistance to Septoria lycopersici. Plant Disease 74: 294-297.

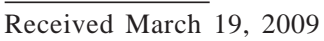

Accepted January 06, 2010 